\title{
WHEN THE RIVER WAKES
}

\section{Rachel Keziah Dibble}

Two cousins living in different countries (Australia and New Zealand) are on a journey of identity connection. The cousins have been watching each other on their journey and supporting through connection on social media platforms. Both cousins are performers in their own ways and through their performance, utilise and question their connections to their Türangawaewae. As they move through their lives there is a connection through their awa that binds them together. Both returned to their river with their tamariki recently, the river is Waingongoro - the snoring waters. This presentation (possibly media performance) is an interview collaboration that evolved as one cousin started on a journey of learning Te Reo in Australia, and one cousin teaches colonisation history. Both cousins feel the flow of their awa within and use social media and digital technology to understand their experience of Te Hurihuri o Te Ao - Our Changing world.

When the River Wakes brings together spoken word and performance from two countries, underpinned by key experiences of their whānau history, and the strength of the awa as it moves through their tears and years of wanting to be in and alongside the river where their tūpuna lived, cried, denied and revived their reo.

Across the ocean you have been calling to the maunga -

Tangaroa carries your cry, your tears and years of yearning.

We carry a certain sort of connection, a passing glance shows the native within us, Many times, unnoticed, and though we might both

Look pretty...

white

Our birth light is told in the star trails of our tūpuna

and the star trails of our tūpuna are reflected

in the river we personify,

not rejected because

Waingongoro is intrinsically in our DNA

Which is to say;

Do Not Assume

that because you cannot hear my karanga, his Tihei Mauri Ora! that

we are not connected here, 
because

our tears fall on scorched earth when we learned of the way the connection was sectioned.

Piece by bloodied piece

to keep the fleece and not the peace;

We learn and cry a river

We will water this land with our tears of birth

\section{Right.}

Discussion One:

My Cousin.

An artist of enthusiastic proportions, connected to Melbourne City, has had dreams in the night of a concrete waka, a poi, a mihi, a boy.

Discussion Two:

Unconnected physically

to his Tūrangawaewae - yet look at him learn about mauri!

but his legs are not ready to stand, authentically, on the stolen land where his whānau live and work their job

His mauri moved by the First people from Te Whenua Moemoeā.

The river there and here, are different

The water flows the same, we speak of the river, we share the same aim

These rivers are our ancestors, our Mothers and our protectors, and we speak faster and louder to make sure our koro, our kuia hear our call but

We are falling

$$
\begin{aligned}
& \text { fall fall falling } \\
&
\end{aligned}
$$

and the crash of the ships of settler colonialism is so very loud, 
when we try to open our mouth, warm our ears,

our reo, our tongue, our waha has been pried

Open, open to the fury of cattle-isation

The history of the ancestors

Turned into a myth, making it easier

To forget about the past

Forget about the last one hundred and eighty years

but when our past carries the tears and the remembering

of Māori migration away

from the mountain and river, the kainga and kōhatu of our ancestors

the remembering becomes harder

when we are no longer in our whenua,

what do we call home?

Where is our future when we have been sleeping in an encouraged

unconsciousness?

Is there something in the water? It is loud and further down

It is dank, and even the eels have nowhere to call home.

It is so cold, and loud,

But it needs to be loud,

Loud enough to drown

The auē of our tangi

It needs to be loud

Louder than the cries of the broken and tortured realities of the babies The babies that had no chance to hear their whanau oriori, a lullaby, to warm them to the magnificence of Tihei Mauri ora!

Have we been sleeping?

Whakarongo, listen to our kuia lament,

her moko kauae within, invisible on her chin,

Whakarongo, listen to Waingongoro, the snoring water, as it threads along, rippling and sparkling, like her long silver hair. 
And at the base of the mountain there is hope,

Water, falling like Grandmother's hair fell down her back, as black as night, for so many years, until finally the toxicity of the dye burned her - and my grandmother allowed her hair to grow untouched and flowing, rippling and sparkling like the long sleepy river, snoring, but awake.

On the banks are coils of koru -

The spiral of infinity leading me back - bring us back and looping us back to black

intergenerational connection to the awa

it intrinsically in our

DNA - which is to say

Do Now Assemble

\section{in the stardust of the night}

Waingongoro snores, Taranaki stands, the kuia whisper

Haere mai, bring your babies home,

haere mai haere mai haere mai

Rachel Keziah Dibble (https://orcid.org/0000-0002-6394-9/20) (Ngāti Ruanui, Ngā Ruahine - BEd, DipTeaching \& Learning (Canterbury University and Christchurch College of Eduation), Grad Dip Tertiary Ed., Cert Mata A Ao Māori) was born and lived around her tūrangawaewae under Taranaki maunga until the age of seven. After a brief time in Australia, she essentially grew up in Ōtautahi (those influential high school years!). After two years in Japan, she completed a Bachelor of Education (Primary). This amused her as initial papers (1992) were in Feminist Studies, however by graduation (200 I) it had morphed to Gender Studies. During this time, Rachel was able to participate in a Tiriti o Waitangi Education course where tauira Māori were in hui separate from tauira Pākehā. The course was facilitated by Irihapeti Ramsden (Ngāi Tahu) and allowed Rachel to experience Mana wāhine and Mana Māori from an institutional perspective. Rachel has continued to utilise the learning from this hui in her teaching. After training, Rachel moved to Dunedin and eventually to Otago Polytechnic as a student, a Student President, as an Executive Assistant the Kaitohutohu office working for Emeritus Professor Khyla Russell and currently is a Senior Lecturer. Influenced by her whānau, the readers, writers, lovers and dreamers they are, Rachel recalls the words of her grandmother, her Taranaki kuia, that being Māori is not "an amount" but "knowing where the bones of your tūpuna lay". As she has read and researched, Rachel has been further influenced by the words of Leonie Pihama, the slam poetry of Te Kahu Rolleston, the art of Robyn Kahukiwa, her aunts and uncles, her own mother and the growing of her own babies, who were able to fully experience putting their whenua into the whenua. 